\title{
The Role of CSR and Partnership Strategy in Improving Loyalty of PT Telkom Foster Partners in Indonesia
}

\author{
Suparjiman $^{1}$, Erika Nurmartiani ${ }^{2}$ \\ \{suparjiman7762@gmail.com ${ }^{1}$ \} \\ Politeknik Piksi Ganesha, Bandung, Indonesia ${ }^{1}$ \\ Universitas Sangga Buana YPKP, Bandung, Indonesia ${ }^{2}$
}

\begin{abstract}
This study aims to look into the impact of CSR and partnership strategy on PT Telkom promote partner loyalty. The quantitative research approach employed is causality research, which will be based on the study objectives. Small and Medium Enterprises (UKM) that have received PT's Corporate Social Responsibility (CSR) program are the unit of analysis. Indonesian telecommunications company Telkom. Meanwhile, the owners and managers of the UKM company are the units of observation. In Indonesia, the population is made up entirely of SMEs whom PT Telkom helps. Therefore, SMEs that PT has directed are the prerequisites to be used as example units. Telkom has a two-year minimum contract. A total of 200 SMEs were randomly selected and distributed over seven regions, with proportional allocation based on the population of each region (Simple Random Sampling). Using Structural Equation Modeling, this analysis will address the research objectives (SEM). The findings of this study show that CSR and partnership strategy impact PT Telkom cultivating partners' loyalty. The partnership strategy more dominantly forms partner loyalty than CSR. Based on this result, it is recommended to manage PT Telkom, who manages the partnership program to develop a partnership strategy: trust, independence, agreement, commitment, and coordination. Besides, it is also necessary to develop CSR in development, utilization, distribution, and impact.
\end{abstract}

Keywords: CSR, partnership strategy, partner loyalty

\section{Introduction}

Small business is one of the businesses that are starting to be a great interest to people in Indonesia. Small business products vary widely, ranging from handicrafts, food, beverages, fashions, beauty tools, and many others. Every year the number of these business actors is increasing and scattered in various parts of the country. Small businesses also contribute to economic growth in Indonesia, with a value of up to $60 \%$. In addition, this small business sector has a major contribution to the circulation of money in society because the amount is quite large, namely IDR 55.2 million.

PT Telkom Indonesia is concerned about and committed to improving the community's quality of life, both economically and socially, by using monies from the company's profit share to enhance the economic and social conditions of the community surrounding the company's active region. 
The Partnership Fund of PT Telkom to Foster Partners from 2001 to 2016 reached IDR3,073,728,342,000.00. These funds are issued through CSR programs and partnership funds. The targets are businesses as Foster Partners, totaling 127,796 SMEs throughout Indonesia. The biggest partnership fund is channeled in the trade sector followed by the service and industry sector. This shows that most of PT Telkom's partnership funds are channeled to businesses in these sectors.

It is vital to have partner loyalty to use PT Telkom Indonesia's products to reach PT Telkom's promoted program. PT Telkom is Indonesia's largest telecommunications firm. Telkom has had a huge subscriber base in the past, which was initially dominated by PSTN services. Telkom's business must change in tandem with technological advancements in order to maintain its position. One service is targeted exclusively to the small company sector, which has a sizable population. Telecommunication infrastructure that is sufficiently established and suitable allows PT Telkom to offer its products and services to this potentially lucrative market. Because of technological advancements, small firms must keep up with business development trends such as e-commerce, which makes transactions more convenient regardless of time or location.

However, data from PT Telkom (2017) shows that the growth of the number of SMEs of PT Telkom fostered partners in the 2012-2016 period has fluctuated. In 2012, there were 9,346 SMEs assisted, decreased to 3,975 in 2013. Then increased again to 12,163 SMEs in 2014. Then decreased to 11,981 in 2015, and 10,956 in 2016.

In addition, in the 2012-2016 period there was also a fluctuation in the total amount of PT Telkom funds channeled to 8 sectors, namely industry, trade, agriculture, livestock, plantations, fisheries, services. The total fund channeled by PT Telkom during this period for the 8 sectors amounted to IDR 1,560,365,000,000.00. However, the numbers have fluctuated. In 2012, disbursed amounting to IDR 343,872 million, decreased to IDR 118,190 million in 2013. Increased to IDR 396,423 million in 2014, IDR 340,958 million in 2015, and to IDR 360,922 million in 2016.

The conditions above indicate the problem of partner loyalty that is not yet high. Meanwhile, loyalty is an aspect that will add to the company's trademark value as a securitization asset [1]. This condition is assumed to be linked to PT Telkom's execution of a partnership strategy. The notion of partnership refers to an endeavor to collaborate with stakeholders, encompassing both vertical and horizontal partnerships, such as those with suppliers and customers and [2]. Meanwhile, the results of Telkom's survey relating to the PT Telkom partnership program (2017) show that the level of effectiveness of the Partnership Program is 69.30. Thus, the Partnership Program implemented by Telkom has not been effective enough to improve the performance of Foster Partners because it has an index below 75. The National Partnership Program Effectiveness Index in 2017 has decreased compared to 2016, which was 76.01 .

There are other aspects that are thought to be related to the above phenomena, namely the implementation of CSR. CSR is a framework that involves an ongoing evaluation of corporate influence and relationships with stakeholders and the environment, as well as identifying and responding to developing strategic opportunities and challenges while advancing company goals [3].

In implementing the CSR program, PT Telkom refers to 3 pillars, namely the Economic Sector, the Social Sector, and the Environmental Sector. The target of economic activities is to prioritize adding value to stakeholders (customers, suppliers, shareholders, government, employees and their families, communities, partners), as well as supporting the improvement of the economy of creative and productive small business communities. Meanwhile, according to 
PT TELKOM's PKBL Opinion Survey Report and CSR Index, 2017, it was found that the national TELKOM Partnership Program CSR Index in 2017 decreased compared to 2016.

Based on the research background, this study aims to examine the effect of CSR and partnership strategy on the loyalty of small business partners under the guidance of PT Telkom throughout Indonesia.

\section{Method}

\subsection{Corporate social responsibility (CSR)}

CSR is an alignment of company activities with social values that integrate the interests of those who are influenced by company activities according to company policies and actions [4]. CSR aims to make the company's activities and culture sustainable in three aspects, namely: Economic aspects, social aspects, and Environmental and Ecological aspects [5].

CSR is a framework that involves an ongoing evaluation of the company's influence and relationships with stakeholders and the environment, as well as identifying and responding to develops strategic opportunities and challenges while advancing company goals [3]. CSR is a situation where companies integrate social, economic and environmental concerns in their business operations and in their interactions with their stakeholders on a voluntary basis [6].

The authors have the same thoughts in defining CSR, such as Herrera [3] and CegarraNavarro et al. [6] have similarities in the dimensions of relationships with stakeholders and the environment. [7], [8], [6], and [4] have similarities on social concerns. So that CSR is a situation where companies integrate social concerns ([6], [7], [8]); relationships with stakeholders ([3], [6]), and the relationship with the economy and the environment ([3], [6]).

Based on the study of the various dimensions of CSR above, where CSR is related to various patterns of relationships with stakeholders, social, ecological, environmental, and sustainable development, hence the dimensions of CSR in this study consist of distribution, utilization, return and impact of assistance.

\subsection{Partnership strategy}

Customer satisfaction, trust, and positive word of mouth are all positively influenced by social issues. Furthermore, the length of a customer-company connection buffers the impact of societal issues on customer satisfaction and trust [9]. As a result of this research, it is clear that customer and social interactions have an impact on consumer trust and happiness, [10] explained, on the other side, that collaborating parties employ trust as a foundation and a paradigm of interdependent assistance, referred to as "Partnerships."

The measurement and assessment of the actual achievement of partner management based on the partnership's programs and objectives is referred to as partnership performance, [11] define the components of the relationship in terms of measurement, which include: Interaction with partners; when firms collaborate to obtain access to resources and lessen environmental risk. Partner commitment is defined as the willingness of both parties to work together to manage the relationship, construct a stable connection, and maintain partnerships at a low cost and build trust in the relationship's stability. Partner coordination or efforts to harmonize channel members' operations within the organization; and Partner trust, or one party's willingness to rely on the other. 
Based on a study of the various dimensions of the partnership, which includes many aspects such as the parties involved in the partnership and their attitudes or characteristics, the dimensions of partnership strategy in this study are: dealing, commitment, coordination, trust, and independence.

\subsection{Partner loyalty}

According to Griffin [12] customer loyalty is defined as non-random purchases expressed from time to time by several decision-making units, and loyal customers will exhibit purchasing behavior, which is defined as non-random purchases expressed from time to time by several decision-making units. Repeat purchases, purchases across product lines, referrals, and immunity are all characteristics of loyal customers.

Loyalty shows customer repurchase behavior [12- [14], for a product or service and immune from other companies' products [12], and shows customers' willingness to recommend products to others [12]. Meanwhile, [15] suggest marketing activities to increase customer loyalty.

The dimensions of repeat purchase measure customer loyalty in this study, defend the company, close to competitive product or service, and recommend the company product, based on a comparison of the dimensions of customer loyalty and according to the research analysis unit.

\subsection{Hypothesis development}

Previous research has shown that CSR has a positive effect on customer loyalty [16]. Customer identification with the company, the emotions it generates, and satisfaction are all positively influenced by CSR. Customer happiness determines loyalty behavior, and identification influences the emotions elicited by service performance. [17]. Therefore, it can be said that CSR affects loyalty. Based on those findings of previous research, the following hypothesis is formulated:

$\mathrm{H}_{1}$ : CSR and partnership strategy affect partner loyalty

Lian and Yoong [18] In relationship marketing, customer pleasure, trust, control mutuality, and communication are examined as relationship quality and client loyalty factors. Customer loyalty was found to be highly influenced by the quality of the relationship. Based on those findings of previous research, the following hypothesis is formulated:

$\mathrm{H}_{2}$ : partnership strategy affects partner loyalty

\subsection{Research methods}

Based on the research objective, the quantitative research method that will be used is causality research. "Causality research is used to obtain evidence of caused-and effect (causal) relationship" [19]. The observation was conducted in the time horizon that is cross section / one shot, in year 2020. "Unit of analysis refers to the aggregation of the data collected during the subsequent data analysis stage" [20]. In this study, the unit of analysis is Small and Medium Enterprises (SMEs) that have participated in PT's Corporate Social Responsibility (CSR) program. Indonesian telecommunications company Telkom. The owners and managers of SMEs are the observational unit.

The population of this study is comprised of all PT Telkom-built Small and Medium Businesses (SME) in Indonesia. SMEs that have become the guidance of PT are the sample unit in terms of SMEs. Telkom's minimum commitment is 2 (two) years, with the expectation that 
the program will have a major impact on customer loyalty to Telkom Indonesia's PT products. Cluster Random Sampling (CRS) is a technique for determining the sample location that involves the following steps:

- Creating a sampling frame, which includes a list of SME Partners Assistance PT Telkom Indonesia, which includes as much as seven regional offices across Indonesia.

- Choosing Witel Partnership SME from Region I to Regional VII to become Bidder Partners for Telkom Indonesia.

- Choosing an existing Partner in Witel-witel to serve as a test location.

According to [21], the minimum sample size should be between 100 and 150 participants. According to [22], a sample size of 100-200 observations is a sufficient minimum limit in most cases. Based on that opinion, a reference to the minimum sample requirements will be applied, and a sample of up to 200 SMEs will be taken. The sample will be distributed to seven regional locations at random, with proportional distribution depending on population in each region (Simple Random Sampling).

Using Structural Equation Modeling, this analysis will address the research objectives (SEM). SEM is used to assess the causal link model between the latent variables and the objectives, methodology, and research model (unobservable variable). SEM (Structural Equation Modeling) is a statistical technique that may directly analyze patterns of association between latent constructs and their indicators, latent constructs and each other, and measurement error. SEM enables for direct comparisons of dependent and independent variables [23].

\section{Results}

\subsection{Goodness of fit}

Statistically evaluation of the overall research model for assessing if a theory-based model fits empirical data. Structural Equation Model (SEM) as a statistical test can explain the goodness of a model with several index criteria to assess the suitability of the model showed on Table 1.

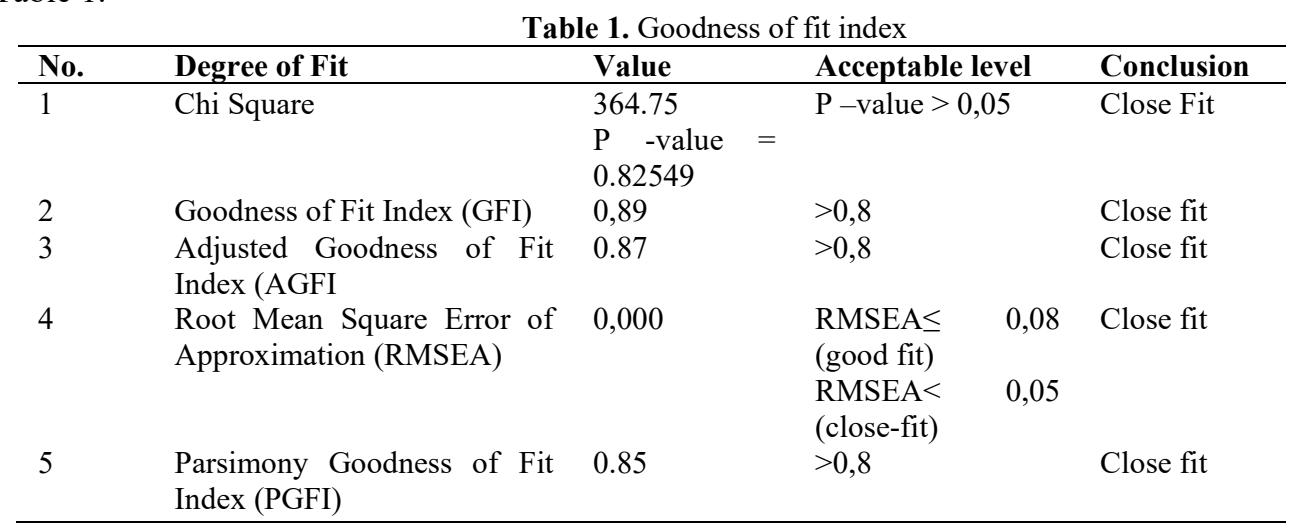

Table 1, Chi-Square value with 364.75 , and $p$-value $=0.82549>0.05$. According to the acce[table level, the suitability of this research model is fit [24]. The RMSEA is 0.000 less than 0.05. Besides that, Goodness of Fit Index (GFI) $=0.89$ and Adjusted Goodness of Fit Index $(\mathrm{AGFI})=0.87>0.80$. In conclusion, for all of values, the research model above is fit. 


\subsection{Structural model}

Therefore, the structural model framework in this study is as follows:

$$
\text { LOYALTY }=0.23 * \text { CSR }+0.54 * \text { Partnership }+\zeta_{1}
$$

The following is the complete path diagram model of the research model in Figure 1.

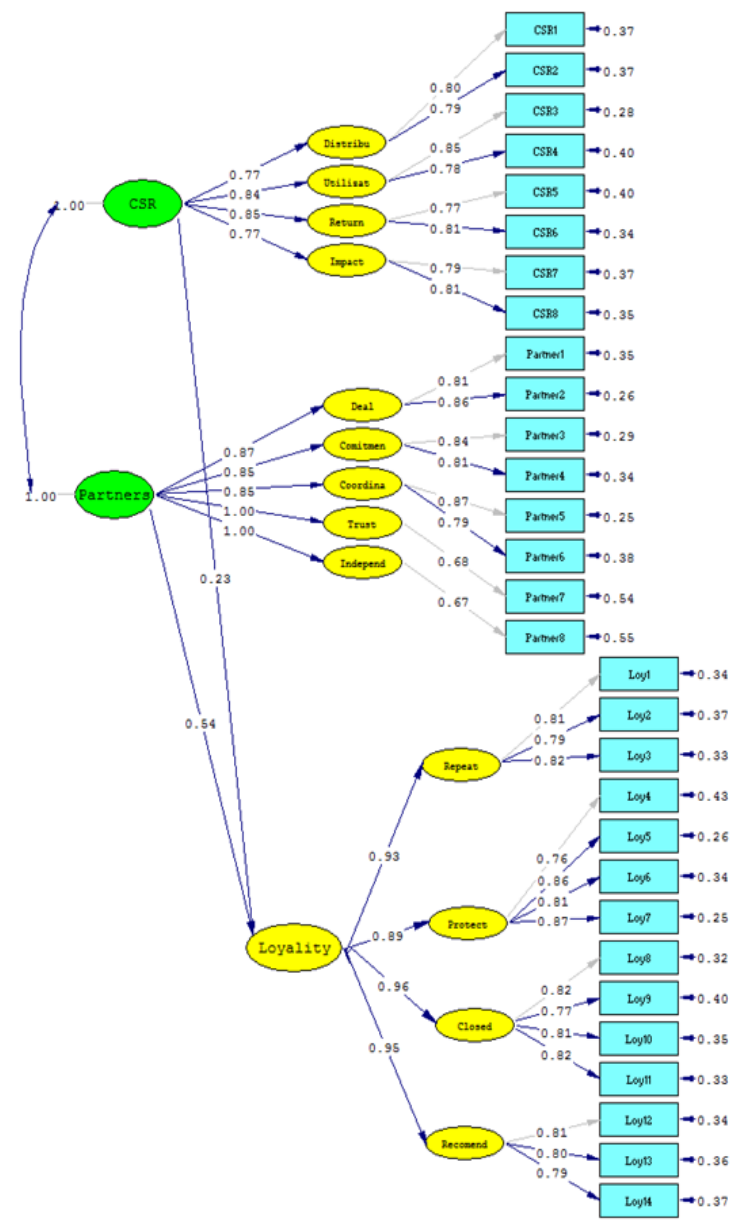

Chi-square $=364.75, d f=391, P-$ value $=0.82549$, RMSEA $=0.000$

Fig. 1. Model testing

\subsection{Measurement model}

The theory is represented by the measurement model, which specifies measurable variables to represent that theory. Then testing the measurement model to indicated indicators and dimensions of each variable are valid and reliable. The loading factor of the measurement model is $>0.50$, and the $t$ value of the loading factor is higher than the $t$-table at a significance of $5 \%$, 
according to [25] dimensions and indicators are valid in measuring latent variables. To determine the amount of reliability of indicators and dimensions in assessing research variables, Composite Reliability and Alpha Cronbach are used. When the Cronbach's Alpha value is better than 0.70 [26], the dimensions and indicators are considered reliable for measuring study variables. Loading factor of research variable showed on Table 2.

Table 2. Loading factor of research variable

\begin{tabular}{|c|c|c|c|c|c|c|}
\hline Variable & Dimension & Indicator & $\lambda$ & $\begin{array}{l}\mathrm{t}- \\
\text { value }\end{array}$ & $\begin{array}{l}\text { Composite } \\
\text { Reliability }\end{array}$ & $\begin{array}{l}\text { Average Variance } \\
\text { Extracted }\end{array}$ \\
\hline \multirow[t]{12}{*}{ CSR } & \multirow[t]{3}{*}{ Distribution } & & 0,77 & 8,65 & \multirow{12}{*}{0,93} & \multirow[t]{12}{*}{0,64} \\
\hline & & CSR1 & 0,80 & - & & \\
\hline & & CSR2 & 0,79 & 8,92 & & \\
\hline & \multirow[t]{3}{*}{ Utilization } & & 0,84 & 10,56 & & \\
\hline & & CSR3 & 0,85 & - & & \\
\hline & & CSR4 & 0,78 & 10,22 & & \\
\hline & \multirow[t]{3}{*}{ Development } & & 0,85 & 9,44 & & \\
\hline & & CSR5 & 0,77 & - & & \\
\hline & & CSR6 & 0,81 & 9,69 & & \\
\hline & \multirow[t]{3}{*}{ Impact } & & 0,77 & 8,65 & & \\
\hline & & CSR7 & 0,79 & - & & \\
\hline & & CSR8 & 0,81 & 9,14 & & \\
\hline \multirow{13}{*}{$\begin{array}{l}\text { Partnershi } \\
\text { p Strategy }\end{array}$} & \multirow[t]{3}{*}{ Dealing } & & 0,87 & 10,71 & \multirow[t]{13}{*}{0,94} & \multirow[t]{13}{*}{0,63} \\
\hline & & Partner1 & 0,81 & - & & \\
\hline & & Partner2 & 0,86 & 11,95 & & \\
\hline & \multirow[t]{3}{*}{ Commitment } & & 0,85 & 10,97 & & \\
\hline & & Partner3 & 0,84 & - & & \\
\hline & & Partner4 & 0,81 & 11,44 & & \\
\hline & \multirow[t]{3}{*}{ Coordination } & & 0,85 & 11,45 & & \\
\hline & & Partner5 & 0,87 & - & & \\
\hline & & Partner6 & 0,79 & 11,42 & & \\
\hline & \multirow[t]{2}{*}{ Trust } & & 1 & 10,27 & & \\
\hline & & Partner7 & 0,68 & - & & \\
\hline & \multirow[t]{2}{*}{ Independence } & & 1 & 10,12 & & \\
\hline & & Partner8 & 0,67 & - & & \\
\hline \multirow[t]{17}{*}{ Loyalty } & \multirow[t]{4}{*}{ Repeat Purchase } & & 0,93 & 11.42 & \multirow[t]{17}{*}{0,96} & \multirow[t]{17}{*}{0,66} \\
\hline & & Loy1 & 0,81 & - & & \\
\hline & & Loy2 & 0,79 & 12.35 & & \\
\hline & & Loy3 & 0,82 & 12,91 & & \\
\hline & \multirow[t]{5}{*}{ Protect } & & 0,89 & 10,32 & & \\
\hline & & Loy4 & 0,76 & - & & \\
\hline & & Loy5 & 0,86 & 12.65 & & \\
\hline & & Loy6 & 0,81 & 11,91 & & \\
\hline & & Loy7 & 0,87 & 12.76 & & \\
\hline & \multirow[t]{5}{*}{ Closed } & & 0,96 & 12,05 & & \\
\hline & & Loy8 & 0,82 & - & & \\
\hline & & Loy9 & 0,77 & 12,48 & & \\
\hline & & Loy10 & 0,81 & 13,26 & & \\
\hline & & Loy11 & 0,82 & 13,51 & & \\
\hline & \multirow[t]{3}{*}{ Recommendation } & & 0,95 & 11,79 & & \\
\hline & & Loy12 & 0,81 & - & & \\
\hline & & Loy13 & 0,8 & 12.71 & & \\
\hline
\end{tabular}




\begin{tabular}{|c|c|c|c|c|c|c|}
\hline Variable & Dimension & Indicator & $\lambda$ & $\begin{array}{l}\mathrm{t}- \\
\text { value }\end{array}$ & $\begin{array}{l}\text { Composite } \\
\text { Reliability }\end{array}$ & $\begin{array}{l}\text { Average Variance } \\
\text { Extracted }\end{array}$ \\
\hline & & Loy14 & 0,79 & 12,51 & & \\
\hline
\end{tabular}

Table 2 describes the analysis of the measurement model of the CSR, partnership and loyalty variables by dimensions and indicators. These results of indicator is valid in measuring its constructs, where the loading factor $>0.70$ and the $t$ value is greater than the $t$ table value (1.96).

\subsection{Hypothesis testing}

The following Table 3 shows the results of the hypothesis testing of this study.

Table 3. Partial Testing

\begin{tabular}{llllll}
\hline \multicolumn{2}{l}{ Hypothesis } & $\gamma$ & $\mathrm{SE}(\gamma)$ & $\mathrm{t}$ - value & $\mathrm{R}^{2}$ \\
\hline 1 & CSR-> Loyalty & $0.23^{*}$ & 0.084 & 2.73 & 0.12 \\
2 & Partnership Strategy-> Loyalty & $0.54^{*}$ & 0.093 & 5.79 & 0.36 \\
\hline
\end{tabular}

*sig. at $0.05(\mathrm{t}$-table $=1.96)$

- $\quad$ CSR and partnership strategy have positive and significant effect on Loyalty with $\mathrm{R}^{2}$ $=0.48$

- $\quad$ Partially, CSR has positive and significant on Loyalty with $\mathrm{R}^{2}=0.12$

- Partially, Partnership strategy has a positive and significant effect on Loyalty with dominant impact $\left(\mathrm{R}^{2}=0.36\right)$

Based on the hypothesis testing, the research model can be shown as follows Figure 2:

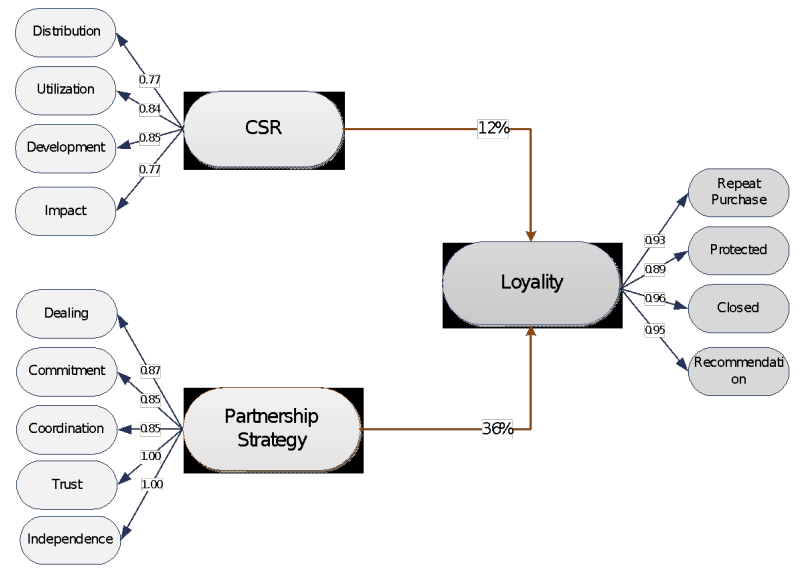

Fig. 2. Research Finding 


\section{Discussion}

The results of this study support the hypothesis that CSR and the partnership strategy affect the loyalty of PT Telkom foster partners. Partner loyalty is more dominantly formed by the partnership strategy than by CSR. Trust and independence are aspects of partnership strategy that has a dominant influence with a coefficient value of 1.00 , followed by dealing $(0.87)$, and then commitment (0.85) and coordination (0.85). Meanwhile, related to CSR, development $(0.85)$ has a more dominant effect, followed by utilization (0.84), distribution (0.77) and impact (0.77).

Trust between the parties in a cooperative relationship makes each of them fulfills its obligations towards the other party. The trust given by Telkom is used by the fostered partners to optimize their business so that they are able to fulfill their predetermined obligations. Independence shows the implementation of cooperation to gain access to resources. This has an impact on the smooth implementation of the foster partner's business activities which in turn has an impact on the achievement of the targets of the fostered partners so as to increase partner loyalty.

The cooperation agreement is carried out in accordance with the partnership contract. The implementation of partnerships supported by the clarity of partnership contracts plays a role in increasing partner loyalty. Commitment shows the willingness of the parties working together to manage the relationship and willingness at low cost. Both things contribute to increase loyalty. Coordination shows efforts to harmonize activities of members within the company and efforts to harmonize activities between company parties. Alignment guarantees the implementation of the business activities of the fostered partners according to what has been determined in an effort to achieve the goals so that the partners are able to fulfill their obligations to Telkom and the impact is increased partner loyalty. After joining Telkom, the fostered partners received a lot of benefits, thus increasing loyalty to Telkom. All fostered partners strongly defend Telkom for profit, so the partnership strategy has an influence on partner loyalty. The results of this hypothesis testing are in accordance with the finding of [18] that customer loyalty is significantly influenced by the quality of the partnership.

In terms of CSR, one of the problems faced by PT. Telkom is the inaccurate target of revolving fund distribution so that it can cause bad credit at the loan repayment stage. Utilization shows the level of compatibility between the use of working capital and investment capital. The formation of partner loyalty is also supported by the extent to which CSR funds are used, namely the level of suitability of the use of working capital and investment capital.

Distribution and impact have the same influence in forming partner loyalty. Distribution is measured by the timeliness of the channel and the suitability of the channel values. The impact is measured by the increased productivity and skills. The results of hypothesis testing show that o time distribution and in accordance with the value of the channel, as well as the increased productivity and behavioral skills of small businesses make an equal contribution in forming partner loyalty.

The results of hypothesis testing, which indicate the influence of CSR on loyalty, provide support for the research results; [16] that CSR positively has a greater impact on customer loyalty, as well as [17] Customer identification with the company, the emotions generated by the company, and satisfaction are all positively affected by CSR. Customer happiness determines loyalty behavior, and identification influences the emotions elicited by service performance. 
Based on these results, it is hoped that this research will benefit the management of PT Telkom in an effort to increase the loyalty of small business partners under the guidance of PT Telkom through the development of a partnership strategy and CSR.

\section{Conclusion}

The results of this study support the hypothesis that CSR and partnership strategy affect the loyalty of PT Telkom foster partners. Partner loyalty is more dominantly formed by partnership strategy than by CSR. The results showed that partnership strategy has a more dominant effect in increasing partner loyalty, so that the management of PT Telkom is advised to make improvements in terms of: trust, independence, agreement, commitment, and coordination. The results also show that CSR has an effect on increasing partner loyalty, so that PT Telkom management is advised to prioritize improvements in terms of: development, utilization, distribution, and impact.

\section{References}

[1] Haaranen T, Nisar TM 2011 Innovative ways of raising funds and adding value: A stakeholder approach to whole business securitization. Bus. Horiz 54, 457-466.

[2] Cravens DW, Piercy NF 2013 Strategic Marketing 10th Edition New York: McGraw-Hill

[3] Herrera M, Jorge M, Sancho, L, Martínez M 2014 Motivaciones hacia la Responsabilidad Social en las Pymes Familiares Revista de Empresa Familiar, 4 (1), 21-44.

[4] Nicolae JC, Sabina JM 2010 Dimensions and challenges of social responsiblity. Annales Universitatis Apulensis Series Oeconomica, 12(1).

[5] Uddin MB, Hassan, MR, \& Tarique, KM 2008 Three dimensional aspects of corporate social responsibility. Daffodil International University Journal of Business and Economics, 3(1), 199-212.

[6] Cegarra-Navarro JG, Reverte C, Gomez-Melero E, \& Wensley AKP 2016 Linking social and economic responsibilities with financial performance: the role of innovation. European Management Journal, 34(5), 530-539. http://dx.doi.org/10.1016/j.emj.2016.02.006

[7] Boyd DE, Clarke T, Spekman R 2014 The Emergence and Impact of Consumer Brand Empowerment in Online Social Networks: A Proposed Ontology. Journal of Brand Management, 21, 516-531.

[8] Wahba H, Elsayed H 2014 The mediating effect of financial performance on the relationship between social responsibility and ownership structure. Future business journal. http://dx.doi.org/10.1016/j.fbj.2015.02.001

[9] Sabiote FE, Roman S 2009 The Influence of Social Regard on the Customer-Service Firm Relationship: The Moderating Role of Length of Relationship. J Bus Psychol 24: pp.441-453.

[10] Hung-Yi Wu, Yueh-Ju Lin, Fei-Liang Chien, Yu-Ming Hung 2011 A study on the relationship among supplier Capability, partnership and competitive Advantage in taiwan's semiconductor industry. International Journal of Electronic Business Management, 9(2), 122-138.

[11] Tsu-Wei Yu, Yung-Ming Shiu 2014 Partnership between life insurers and their intermediaries. Management Research Review, 37(4), 385-408, https://doi.org/10.1108/MRR-11-2012-0243.

[12] Griffin J 2002 Customer Loyalty How to Earn it, How to Keep it. Lexington Books. Singapore.

[13] Oliver RL 1997 Satisfaction A Behavioral Perspective on the Consumer. McGraw-Hill Education, Singapore.

[14] Sivadas E, Baker-Prewitt JL 2000 An examination of the relationship between service quality, customer satisfaction, and store loyalty. International Journal of Retail \& Distribution Management, 28(2), pp.73-82, https://doi.org/10.1108/09590550010315223

[15] Kotler P, Keller KL 2016 Marketing Management global edition Pearson 
[16] Kim S, \& Kim D 2016 The influence of corporate social responsibility, ability, reputation, and transparency on hotel customer loyalty in the U.S.: A gender-based approach. Springer Plus, 5(1), 113. http://dx.doi.org/10.1186/s40064-016-3220-3.

[17] Pérez A, Rodríguez DB 2015 An integrative framework to understand how CSR affects customer loyalty through identification, emotions and satisfaction. Journal of Business Ethics, 129(3), 571584. http://dx.doi.org/10.1007/s10551-014-2177-9

[18] Song Bee Lian dan Liew Chee Yoong 2017 The Effectiveness of Strategic Relationship Marketing: Exploring Relationship Quality towards Customer Loyalty. International Business Research; 10(12), 159-166.

[19] Malhotra NK 2010 Marketing research: An applied orientation (6th ed.). New Jersey: Prentice Hall.

[20] Sekara, U, Bougie R 2010 Research methods for business A skill-building approach (5th ed.). Haddington John Wiley \& Sons.

[21] Schumacker RE, Lomax, RG 2004 A beginner's guide to structural equation Modeling (2nd ed.). Lawrence Erlbaum Associates Publishers.

[22] Kelloway EK 1998 Using LISREL for structural equation modeling: A researcher's guide. Thousand Oaks, CA: Sage.

[23] Hair JF, Anderson RE, Tatham RL, Black WC 1992 Multivariate Data Analysis with Readings, 3rd edn. Macmillan, New York.

[24] Hair jr et.al. 2010 Multivariate Data Analysis (7th ed). United States: Pearson

[25] Chin WW 2000 Partial least square for iS researchers: an overview and presentation of recent advances using the PLS approach. Conference: Proceedings of the twenty first international conference on information systems.

[26] Nunnally JC, Bernstein IH 1994 The Assessment of Reliability. Psychometric Theory, 3, 248-292. 